\title{
Irpe The Rise of Rentier Capitalism and the Financialization of Real Sectors in Developing Countries
}

\author{
FIRAT DEMIIR \\ Department of Economics, University of Oklahoma; \\ e-mail:fdemir@ou.edu
}

\begin{abstract}
Using microlevel company panel data, the article analyzes the impacts of financial liberalization on real investment behavior under capital market imperfections, volatile macroprices, and changing country risk levels. The findings suggest that financial liberalization in developing countries has become instrumental in channeling real sector savings to speculative short-term investments instead of long-term investment projects and hence altering the pattern of capital accumulation in the real sectors of the economy.
\end{abstract}

JEL classification: C33, E22, 016

Keywords: private investment; macroeconomic uncertainty; financial markets; financialization; low-growth traps

\section{Introduction}

The difficulty of converting the commodity into money, of selling it, only arises from the fact that the commodity must be turned into money but the money need not be immediately turned into commodity, and therefore sale and purchase can be separated. . . . this form contains the possibility of crisis. Crisis is nothing but the forcible assertion of the unity of phases of the production process which have become independent of each other. (Marx 1968: 509, emphasis added)

The economic and, in particular, the financial landscape of both developed and developing countries have gone through a radical transformation since the early 1980s and

Author's Note: The article is based on the second essay of my PhD dissertation. I am thankful to Jaime Ros, my dissertation advisor, and to my committee members, Amitava K. Dutt, Kwan S. Kim, and Kajal Mukhopadhyay, for their helpful comments and suggestions. I also thank Al Campbell, Erinç Yeldan, and other session participants at Union for Radical Political Economics (URPE) at Allied Social Sciences Association 2007 meetings in Chicago, the Association for Economic and Social Analysis 2006 conference at the University of Massachusetts-Amherst, and the RRPE reviewers for their constructive comments. For financial support, I would like to thank the Helen Kellogg Institute for International Studies. A more detailed version of the article is available at http://faculty-staff.ou.edu/D/Firat.Demir-1/.

Review of Radical Political Economics, Volume 39, No. 3, Summer 2007, 351-359

DOI: $10.1177 / 0486613407305283$

(C) 2007 Union for Radical Political Economics 
1990s. Daily foreign exchange (FX) trading has skyrocketed with an ever-increasing gap between real and financial sector activities, where the annual FX trading-to-world trade ratio has steadily increased from 2:1 in 1973, to 10:1 in 1980, and 90:1 in 2004. Meanwhile, FX trading/World GDP reached 17:1 as of 2004 (Bank for International Settlements 2005; World Bank 2006).

Apart from the gross figures that reflect the total expansion of international financial transactions, in terms of the net resource flows to developing countries, the scoreboard of the last decade is far from spectacular. Net transfers of financial resources to developing countries have been $-\$ 1,177$ billion between 1993 and 2004, with an annual average of -\$98 billion (United Nations 2005). In the case of foreign direct investment (FDI) inflows, which are the type of flows generally praised for their benevolent nature, the majority of them are still between developed countries. As of 2004, 94 percent of FDI inflows (excluding China) went to developed countries (United Nations Conference on Trade and Development [UNCTAD] 2005).

In contrast, among countries that import capital, the United States stands alone with a share of 65 percent among all others as of 2005 (International Monetary Fund [IMF] 2006). Despite this, countries around the world are continuing to adopt neoliberal policies to attract foreign capital at an increasing pace: 87 percent of 271 national regulatory changes in 102 countries in 2004 made it more favorable for foreign companies to enter and operate. The average in 64 countries between 1991 and 2004 is 154 legislative changes a year, of which 93 percent are more favorable to FDI (UNCTAD 2005).

Nevertheless, the warning signs of global imbalances are continuing to grow with an increasing scale and frequency of financial crises. Between 1980 and 1995, almost threequarters of 181 members of the IMF had one or more periods of banking crisis or "significant banking problems" (Felix 1998: 164).

As a result of this radical expansion of financial sector activities, global capital flows, and financial instability, the majority of papers have focused on macro-interactions between financial flows and investment-growth performance without exploring the changes taking place at the microlevel.

It is my contention that during this period, real sector firms also went through a radical metamorphosis from being primarily involved in real sector activities to becoming financial rentiers themselves. In this respect, there is growing research to explain this transition that can be classified under the "financialization" literature (see Crotty 2005; Dumenil and Levy 2005; Epstein and Jayadev 2005; Felix 1998). Accordingly, the key features of financialization can be summarized as (a) increasing acquisition of short-term financial assets by the real sector firms, (b) decreasing fixed investment rates, and (c) increasing real rate of return on financial capital over and above the rate of return on fixed capital.

The question I ask here is whether financial liberalization encourages and stimulates long-term investment in the real sectors of the economy such that it would compensate the negative effects of the reform programs (e.g., higher volatility) or further hamper growth by creating new distortions.

Given the lack of microlevel analysis of developing country experiences, I have focused on three emerging markets - Argentina, Mexico, and Turkey-which appear as a trio where financial liberalization was first started and the experiences of which have 
formed the theoretical and ideological basis of the arguments on liberalization of markets in the developing world. With this research, I not only expect to provide empirical support to the financialization literature in the case of developing countries, but I also hope to overcome some data limitations faced by previous researchers in the field regarding accounting data mining.

As is well documented, following financial liberalization, serious bottlenecks have remained in the developing world: (a) persistence of credit market imperfections with a lack of long-term credit availability, and (b) higher levels of uncertainty and volatility in key macro- and microprices. Under these rigidities, I argue that in the aftermath of liberalization programs, real sector firms faced a portfolio allocation problem between two types of investments: fixed versus financial. My starting point is that increasing uncertainty and volatility in the macroeconomic environment, lack of credit availability, and increasing competition in the goods markets, when combined with the availability of higher returns in the financial sectors, may encourage rentier-type financial investments at the expense of real investment projects. In other words, financial liberalization programs combined with domestic rigidities may become instrumental in channeling real sector savings to speculative short-term investments instead of long-term capital formation and hence alter the pattern of capital accumulation in the real sectors of the economy.

Furthermore, I also challenge the findings of the literature on the relationship between cash flow and real investment by suggesting that profits from fixed and financial investments may have different effects on new fixed investment decisions under credit constraints. My main objection is that if the real sector firms face these two types of investments when allocating their resources, then their decisions will depend on the respective rates of return from them. Accordingly, I expect to find that although profits from operational activities are a likely source of financing for fixed investment, profits from financial activities are not necessarily so.

As a result, short-term distortions in real sector investment decisions may lead to financialization and thereby a deindustrialization run in these economies by encouraging rentier-type investments.

\section{Financial Liberalization, Growth, and Investment}

Despite a lack of consensus on the underlying factors, there is no disagreement on the slowdown of growth and investment in the aftermath of the Keynesian golden age in both developed and developing countries. During this period, in the case of the United States, mostly owing to financial liberalization, the ratio of profits of financial corporations to the profits of nonfinancial corporations (NFC) rose from around 15 percent in the early 1950s and 1960s to around 50 percent in 2001 (Crotty 2005). The figures are comparable to other developed countries where we also have seen a jump in rentier incomes of financial firms (Epstein and Jayadev 2005).

When looking at the growth-liberalization relationship, although there seems to be a strongly positive impact of capital account liberalization on growth in the case of highincome countries, there is no strong evidence in the case of developing countries (Durham 2002; Edwards 2001; Rodrik 1998). Regarding the net effect of the financial liberalization 
programs, in contrast to initial neoclassical predictions, we find higher real interest rates, persistent credit rationing, lack of long-term credit (Demir 2004; Economic Intelligence Unit 2003a, 2003b; Fanelli, Rozenwurcel, and Simpson 1998), and increasing risk and uncertainty in key macroprices (Calvo, Leiderman, and Reinhart 1993; Frenkel and Rozada 2000; Gabriele, Boratav, and Parikh 2000). There is increasing evidence suggesting that during this period, "financial markets lowered growth, eroded profitability, and shortened the planning horizons of the large NFCs" (Crotty 2005: 7; see also Demir 2007).

In Marxian terms, we may be back to the good old circuit of MCM (money-commoditymoney plus profit), where capital decides (because of the reasons discussed) to stay in liquid form to achieve MM (money-money plus interest) without transforming back into commodity capital. ${ }^{1}$ In this respect, also from a Keynesian perspective, increasing volatility following financial liberalization may become self-exacerbating as the investors shorten their time horizons either to benefit from speculative gains or to avoid excess risk, which in turn further increases volatility. As a result, increasing macrovolatility may lead to a slowdown of investment in the real sectors (Keynes 1964: chapter 12).

\section{Empirical Testing}

Following the previous discussion, first I distinguish financial and real investments that a real sector firm faces under a liberalized domestic market. Second, I revisit the effects of financial constraints on investment decisions by differentiating profits from operational and nonoperational activities when analyzing their impacts on fixed investments of real sector firms.

In what follows, the financial profits variable is defined as the realized financial income net of financial expenses except interest cost. Namely, it includes dividend income plus interest income, plus net gain from FX transactions, plus other income from other operations net of losses and expenses from such operations. The operational profits are defined as net-operating revenues minus cost of goods sold, minus operating expenses. The financial assets include current assets and short-term investments (stocks, treasury bills, government bonds, etc.). Net fixed assets include all the existing capital stock net of land and depreciation.

Accordingly, the following hypotheses are tested separately for each country:

1. Financial liberalization encourages real sector firms to invest more in short-term liquid assets rather than long-term fixed assets. The main triggering factors are (a) availability of increasing rates of returns in the financial markets, (b) increasing instability and uncertainty in key macroprices and country risk levels, and (c) lack of long-term credit availability. For empirical testing, the changes in the portfolio allocations of real sector firms between financial assets and fixed assets must be analyzed in the presence of these three factors. Accordingly, the relationship is tested by equation (1):

$$
f a f a_{i t}=\alpha_{i}+\alpha_{1} C R_{t}+\alpha_{2} P_{i t}+\alpha_{3} S_{i t}+\alpha_{4} C_{t}+\alpha_{5} I C F_{t}+\alpha_{6} V_{t}+d+\varepsilon_{i t}
$$

For all equations, $i=1, \ldots, N$ and $t=1, \ldots, T$ respectively refer to the cross-section and time series elements of the data. Here, $\alpha_{i}$ is a firm-specific effect, and $d$ is a vector of time, period, and sector specific effects.

1. For a discussion of the role of financial intermediation in Marxian crisis theory, see Crotty (1985). 
$f a f a_{i t}$ is the financial assets-to-fixed assets ratio representing the portfolio allocation decisions of real sector firms.

$C R_{t}$ refers to a vector of different country risk and macro-instability and uncertainty measures (including uncertainty in manufacturing inflation and real exchange rates).

$P_{i t}$ refers to profitability measures for different assets and includes real rate of return on financial assets (RRRF) and rate of return on fixed assets (RRK). I expect RRRF to have a positive coefficient suggesting that increasing rate of return on financial assets encourages firms to divert more of their investments toward financial assets while the opposite for RRK.

$S_{i t}$ refers to aggregate demand variables, including net sales per firm and real GDP growth.

$C_{t}$ refers to total credit from the banking system to the private sector as a share of GDP.

$I C F_{t}$ refers to international capital flows and includes net real short-term capital inflows (SCF) and FDI inflows by nonresidents.

$V_{t}$ refers to a vector of control variables, including $K P$, which refers to relative price of fixed investment goods; $R W$ refers to real wages; and $T O$ refers to trade openness measured as exports plus imports over GDP.

2. If hypothesis 1 is correct, then the weight of financial profits in total profits should also become dependent on expected risk perceptions, country risk, and rate of return in the financial markets. Therefore, in the presence of uncertainty and risk, the profitability of firms should be closely linked with changing shares of financial and operational profits in overall profits. The relationship is tested by equation (2):

$$
\text { fpns }_{i t}=\alpha_{i}+\alpha_{1} C R_{t}+\alpha_{2} G D P_{t}+\alpha_{3} C_{t}+\alpha_{4} I C F_{t}+\alpha_{5} V_{t}+d+\varepsilon_{i t}
$$

fpns $_{i t}$ is the financial profits to net sales ratio.

$C R_{t}, I C F_{t}$, and $C_{t}$ are the same as in equation (1).

$G D P_{t}$ is the real GDP growth rate.

$V_{t}$ is a vector of control variables, including the following: Inf that is manufacturing inflation to correct for changes in the financial profits caused by purely inflationary reasons; $G$ is the consolidated government budget balance; $R W$ is real wages; and $T O$ includes trade openness and terms of trade.

3. Even if hypotheses 1 and 2 were correct, this (financialization) might not necessarily reflect a negative development for real sector firms. For example, if it is true that financial investments and financial profits increase along with increasing risk and uncertainty, this may have a counterbalancing impact on the overall profitability of private firms, which would positively affect new investment decisions (given capital market imperfections). Therefore, it is necessary to reanalyze the cash flow/investment relationship without presuming that all components of cash flow and profit measures have the same effect on investment.

In addition, I also replicate other research on the effects of uncertainty and country risk on private fixed investment decisions. Accordingly, along hypothesis 1, private firms are expected to reduce their new fixed investment spending in the face of increasing risk or uncertainty.

The relationship is estimated by the following equation:

$$
I_{i t}=\alpha_{1} I_{i t-1}+\alpha_{2} I_{i t-2}+\alpha_{3} K O_{i t-1}+\alpha_{4} K O_{i t-2}+\alpha_{5} C R_{t}+\alpha_{6} P_{i t}+d+\varepsilon_{i t},
$$


where the left-hand side variable is the real net fixed investment of firm $i$ in year $t$ and is measured by the logarithmic difference of net fixed capital stock at constant prices $\left(\Delta k_{i t}\right)$.

$K O_{i t}$ is the capital/output ratio and is based on the assumption that output and capital are proportional in the long run with short-term fluctuations.

$P_{i t}$ is a set of profitability measures reflecting the expectations about future profitability as well as the effects of financial constraints. It includes (a) current and lagged ratios of financial and operational profits to beginning capital stock, which capture the effects of financial and liquidity constraints as well as effects of changes in profitability of different types of investments (financial vs. real), and (b) rates of return on fixed (RRK) and financial (RRRF) assets, where the latter captures not only the market signals regarding future profitability in nonoperational activities but also the effects of opportunity costs on fixed investment. Accordingly, to the extent that the rate of return on financial assets reflects the opportunity cost of fixed investment as well as future profitability, it is expected to have a negative coefficient.

$C R_{t}$ and $d$ are the same as before.

\section{I Data}

The data sets are from the audited financial accounts of publicly traded industrial firms in Argentina, Mexico, and Turkey and are unbalanced. The period analyzed is biannual and covers 1991:1-2001:2 for Argentina, 1990:1-2003:2 for Mexico, and 1992:1-2003:2 for Turkey. The primary reason for using biannual data is to capture the effects of changes in profitability (especially financial) and risk conditions on the investment positions of firms. The firms included are all industrial, with the majority of them in manufacturing-related activities. There are 66, 80, and 179 firms in the final data set, respectively.

\subsection{Estimation}

To test hypotheses 1 and 2, an instrumental variable procedure is applied to control for the possibility of parameter endogeneity among the variables. In the estimation, a twostaged least squares method is employed. All regressions initially included time, period, and industry dummies. For equation (3), to correct for parameter endogeneity as well as the correlation between the lagged $I$ and the firm-specific effects and the error term, I used a generalized method of moments estimator by Arellano and Bover's (1995) orthogonal deviations transformation.

\section{Results ${ }^{2}$}

\section{I Hypothesis I}

In all three cases, I have found that increasing country risk, uncertainty, and volatility in key macroprices as well as increasing interest rates encourage financial investment over fixed investment. As expected, firms in their investment decisions also take into account respective rate of returns on financial and fixed assets. When looking at the effects of credit

2. The detailed regression tables are available from the author. 
availability, increasing credit generation is found to reduce $f a f a$ at a significant rate. In the case of aggregate demand and growth effects, both GDP growth and increasing sales are found to decrease the fafa ratio significantly. Last, I found that although in Argentina and Mexico SCF increases the financial assets to fixed assets ratio ( $f a f a)$, in the case of Turkey it decreases. On the other hand, in all countries, FDI flows are found to be increasing the fafa ratio significantly.

\subsection{Hypothesis 2}

The findings show that increasing country risk, uncertainty, and volatility in real exchange rates and producer prices and rising real interest rates increase the fpns ratio. In contrast, increasing GDP growth or credit generation is found to reduce the share of financial profits. In the case of the short-term capital inflows variable, I found that in all three cases, rising inflows increase the financial profits more than the operational ones.

\subsection{Hypothesis 3}

The results indicate the presence of credit constraints in all three cases where operational profits have a significant effect on fixed investment. In contrast, however, the sign and/or size of the effect of financial profits differ considerably from the operational ones. In the case of Argentina and Mexico, a significantly negative relationship is discovered between financial profits and private investment with very close coefficients. In the case of Turkey, however, a positive relationship is found, suggesting that financial profits are indeed used for financing new investment. However, in comparison, the financial profits are found to have an almost fifteen times smaller economic effect on fixed investment than operational profits.

When looking at the effects of rates of returns on fixed and financial assets, in all three cases, increasing rates of return on financial assets reduce fixed investment, whereas the opposite is true for the rate of return on fixed assets.

Finally, when analyzing the effects of country risk and uncertainty variables, the empirical results confirm the findings of previous research and suggest a negative and statistically significant relationship between risk/uncertainty and private investment.

\section{Conclusion}

The above results not only provide empirical support to the financialization hypothesis but also highlight certain differences in its development paths between developed and developing countries. In my view, the main push for financialization and shortening of NFC investment planning primarily resulted from increasing risk and uncertainty as well as from the availability of high short-term returns in the financial markets. The increasing product market competition following trade and capital account liberalization further contributed to this. There are, however, commonalities as well: the financialization in both developed and developing countries appear to be a reaction by the NFC to the falling rate of profit because of rising interest costs. According to Dumenil and Levy's (2005) estimates in France, about 2.4 percentage points of profits were lost because of interest 
payments from the mid-1980s and 1.7 percentage points in the United States. In this respect, in an attempt to diminish the debt burden, I can argue the NFCs themselves have become rentiers. A second common element is the increasing profitability of financial sector firms vis-à-vis the NFC following financial liberalization. Crotty (2005) shows that the ratio of NFC portfolio income to cash flow rose from around 14 percent in the 1960s to around 37 percent toward the end of the 1990s in the United States. Similarly, in the case of Turkey, the share of financial revenues in net profits jumped up to 547 percent in 2001 from around 15 percent in 1982.

Given the previous findings, I suggest that there is a strong need to reorganize the financial system in such a way that national (and foreign) savings are directed toward productive investments instead of financial ones. To realize this, some of the policy recommendations include (a) providing macro- and microeconomic stability through preventing sharp fluctuations in the financial markets and in international capital flows, (b) reducing real interest rates, (c) opening up of credit channels for real sector firms' access to long-term investment financing, and (d) reducing public sector borrowing requirements so that they will not crowd out private funds for real investment projects or increase interest rates.

\section{References}

Arellano, M., and O. Bover. 1995. Another look at the instrumental variable estimation of error-components models. Journal of Econometrics 68: 29-51.

Bank for International Settlements. 2005. Triennial central bank survey. Basel, Switzerland: Author.

Calvo, G. A., L. Leiderman, and C. M. Reinhart. 1993. Capital inflows and real exchange rate appreciation in Latin America: The role of external factors. IMF Staff Papers 40: 108-51.

Crotty, J. 1985. The centrality of money, credit and financial intermediation in Marx's crisis theory. In Marxian political economy: Essays in honor of Harry Magdoff and Paul Sweezy, ed. S. Resnick and R. Wolff, 45-82. New York: Autonomedia.

- 2005. The neoliberal paradox: The impact of destructive product market competition and "modern" financial markets on nonfinancial corporation performance in the neoliberal era. In Financialization and the world economy, ed. G. Epstein, 77-110. Northampton, MA: Edward Elgar.

Demir, F. 2004. A failure story: Politics and financial liberalization in Turkey, revisiting the revolving door hypothesis. World Development 32: 851-69.

2007. Determinants of manufacturing firm profitability under uncertainty and macroeconomic volatility: Evidence from an emerging market. Mimeo, University of Oklahoma.

Dumenil, G., and D. Levy. 2005. Costs and benefits of neoliberalism: A class analysis. In Financialization and the world economy, ed. G. Epstein, 17-45. Northampton, MA: Edward Elgar.

Durham, J. B. 2002. The effects of stock market development on growth and private investment in lowerincome countries. Emerging Markets Review 3: 211-32.

Economic Intelligence Unit. 2003a. Country finance, Mexico. London: Author. 2003b. Country finance, Turkey. London: Author.

Edwards, S. 2001. Capital flows and economic performance: Are emerging economies different? NBER Working Paper 8076. Cambridge, MA: National Bureau of Economic Research.

Epstein G. A., and A. Jayadev. 2005. The rise of rentier incomes in OECD countries: Financialization, central bank policy and labor solidarity. In Financialization and the world economy, ed. G. Epstein, 46-74. Northampton, MA: Edward Elgar.

Fanelli, J. M., G. Rozenwurcel, and L. M. Simpson. 1998. Financial reform in developing countries: Argentina. In Financial reform in developing countries, ed. J. M. Fanelli and R. Medhora, 31-56. New York: St. Martin's Press. 
Felix, D. 1998. Asia and the crisis of financial globalization. In Globalization and progressive economic policy, ed. D. Baker, G. Epstein, and R. Pollin, 163-91. Cambridge, UK: Cambridge University Press.

Frenkel, R., and M. G. Rozada. 2000. Balance of payments liberalization: Effects on growth, employment and income in Argentina. CEPA Working Paper Series 1(13) (February). New York: Center for Economic Policy Analysis, New School University.

Gabriele, A., K. Boratav, and A. Parikh. 2000. Instability and volatility of capital flows to developing countries. The World Economy 23: 1031-56.

International Monetary Fund. 2006. Global financial stability report. Washington, DC: International Monetary Fund.

Keynes, J. M. 1964. The general theory of employment, money and interest. New York: Harcourt Inc.

Marx, K. 1968. Theories of surplus value, vol. II, ch. XVII. Moscow: Progress Publishers.

Rodrik, D. 1998. Who needs capital account convertibility? In Should the IMF pursue capital account convertibility? Essays in International Finance no. 207, ed. P. Kenen, 55-65. Princeton, NJ: Princeton University Press.

United Nations. 2005. World economic and social survey 2005. New York: United Nations.

United Nations Conference on Trade and Development. 2005. World investment report. Geneva, Switzerland: United Nations.

World Bank. 2006. World development indicators online dataset. Washington, DC: World Bank.

Firat Demir is an assistant professor of economics at the University of Oklahoma and received his PhD from the University of Notre Dame in 2006. His research is focused on international finance and development economics and, in particular, the role of the globalization of financial markets in determining growth and development paths followed by developing countries. His recent publications include "Macroeconomic Uncertainty and Private Investment in Argentina, Mexico, and Turkey," "A Failure Story: Politics and Financial Liberalization in Turkey," and "Militarization of the Market and Rent Seeking Coalitions in Turkey." 